\title{
KOMPETENSI GURU PENDIDIKAN ANAK USIA DINI
}

\author{
Ta'rif
}

Lahir di Indramayu، 2 April 1975. Menyelesaikan pendidikan S1 pada Fak. Dakwah UIN Syarif Hidayatullah Jakarta, tahun 1999 dan 52 Prog. Studi Islam tahun 2007 pada universitas yang sama. Saat ini sebagai kandidat Peneliti pada Puslitbang

Pendidikan Agama dan Keagamaan Badan Litbang dan Diklat Departemen Agama RI

\section{Abstract}

Teacher is an urgent and determinative factor in education. It has a central and determinative position in the learning process. The education society prosecutes in the improvement of the teacher quality. It could not posponed anylonger, as what implicitly shown at Law Number 20 of 2003 on National Education System, Law Number 14 of 2005 on Teacher and Lecturer, and Government Regulation Number 19 of 2005 on National Standard of Education. Furthermore, the implementation of competence based curriculum $(K B K)$, and then Kurikulum Tingkat Satuan Pendidikan (KTSP), brings on educators to have an enough competence. The research elaborates the competence of teacher in Raudhatul Atfal/ Bustanul Alfal (islamic kindergarten)-including professional, paedagogic, personal and sosial competence in 6 cities as locus of this research. 
Keywords: competence, teacher, children education

\section{Pendahuluan}

\section{A. Latar Belakang}

Tujuan pendidikan nasional dalam UU Sisdiknas No. 20 Tahun 2003 ialah untuk mengembangkan potensi peserta didik agar menjadi manusia ber-iman yang bertakwa kepada Tuhan Yang Maha Esa, berakhlak mulia, sehat, berilmu, cakap, kreatif, dan menjadi warga negara yang demokratis serta bertanggungjawab. Untuk mendukung tujuan tersebut diperlukan semua unsur yang terlibat dalam sistem pendidikan melakukan sinergi membentuk kekuatan yang tangguh, sehingga dapat mewujudkan pendidikan yang bermutu. Tanpa sinergi unsur-unsur pendukung seperti pemerintah, sekolah, guru, masyarakat dan orang tua, pendidikan akan sulit menghasilkan mutu yang betkualitas dan memiliki daya saing dengan negara-negara lain.

Salah satu unsur penting dalam meningkatan mutu pendidikan adalah guru. Guru merupakan faktor penentu yang krusial bagi keberhasilan pembangunan pendidikan dan peningkatan kualitas pendidikan di masa depan. Undang Undang Nomor 20 tahun 2003 tentang Sisdiknas, pasal 29 ayat 2 menyebutkan bahwa pendidik merupakan tenaga profesional yang ber- tugas metencanakan dan melaksanakan proses pembelajaran, menilai hasil pembelajaran, melakukan pembimbingan dan pelatihan. Sudjana (1995: 5) menyebutkan bahwa guru memiliki kedudukan sentral, karena perannya sangat menentukan dalam proses pembelajaran. Meski proses pendidikan melibatkan berbagai unsur antara lain: kurikulum, sarana-prasarana, penilaian dan lain-lain, guru tetap memiliki peran strategis dalam menggerakkan semua unsur tersebut. Lebih lanjut, Usman (1997:4) menyatakan bahwa guru berperan dalam menciptakan serangkaian perilaku yang saling berkaitan dengan perubahan perilaku dan perkembangan siswa.

Guru pada tingkat pendidikan anak usia dini (PAUD) merupakan tenaga pendidik pada usia pra sekolah, pada usia inilah peran guru akan menentukan pendidikan selanjutnya, sebagaimana disebutkan UU No. 20 Tahun 2003 pasal 1 ayat (14) dinyatakan bahwa pendidikan anak usia dini adalah suatu upaya pembinaan yang ditujukan kepada anak sejak lahir sampai dengan usia enam tahun yang dilakukan melalui pemberian rangsangan pendidikan untuk membantu pertumbuhan dan perkembangan jasmani dan rohani agar anak memiliki kesiapan dalam memasuki pendidikan lebih lanjut. Pendidikan anak usia dini 
juga tidak hanya mengharapkan agar anak-anak lebih siap belajar di sekolah dasar, tetapi lebih jauh dari itu, anak diharapkan sejak dini mendapat rangsangan inteletual, sosial dan emosional sesuai dengan tingkat perkembangan usianya. Perkembangan kecerdasan anak pada masa ini mengalami peningkatan dari $50 \%$ sampai $80 \%$. Selain itu, hasil penelitian yang dilakukan Pusat Kurikulum Balitbang Diknas Tahun 1999 menunjukkan bahwa ham-pir pada seluruh aspek perkembangan anak yang masuk TK/ RA mempunyai kemampuan lebih tinggi daripada anak yang tidak masuk TK/RA. ${ }^{1}$ Darigambaran tersebut guru PAUD perlu memiliki kompetensi yang memadai yang pada akhirnya dapat menyiapkan anak usia dini yang siap secara mental maupun spiritual.

Berbarengan dengan itu, tuntutan terhadap profesionalisasi dalam setiap bidang pekerjaan yang tergambar pada sertifikasi dan akreditasi yang harus dimiliki oleh tenaga kerja profesional seperti guru. Tuntutan tersebut direspons pemerintah dengan menetapkan standarisasi kompetensi guru sebagaimana tercantum dalam pelayanan minimal serta pedoman penyusunan standar pendidikan dasar dan mene- ngah, keputusan ini dipertegas dalam UU No. 20 tahun 2003, UU No. 14 Tahun 2005 tentang Guru dan Dosen, Peraturan Pemerintah No. 19 Tahun 2005 tentang Standarisasi Nasional Pendidikan. Selain itu, penerapan pendidikan berbasis kompetensi kemudian adanya kurikulum tingkat satuan pendidikan (KTSP) memberikan implikasi terhadap pengelola pendidikan terutama guru yang dituntut memiliki kompetensi yang memadai. UU No. 14 Tahun 2005 pada pasal 10 ayat (1) disebutkan, bahwa guru harus memiliki beberapa kualifikasi yaitu dalam bidang akademik dan komptensi yang diperoleh melalui pendidikan profesi. Dari segi kompetensi seorang guru harus memiliki empat kompetensi, yang meliputi kompetensi pedagogik, kompetensi kepribadian, kompetensi sosial dan kompetensi professional. Hal ini berarti, bahwa guru pendidikan anak usia dini (PAUD) khususnya dan ketenagaan pendidikan umumnya dituntut untuk memiliki kompetensi-kompetensi tersebut. Seorang guru dinyatakan kompeten, jika guru tersebut secara nyata memiliki kemampuan dan keterampilan dalam menjalankan tugas (profesi) keguruannya secara pro- 
fessional sesuai dengan tuntutan jabatan keguruannya, yaitu mampu dan terampil untuk membelajarkan peserta didik yang dibimbingnya secara efektif, efisien dan terpadu.

\section{B. Masalah Penelitian}

Berdasarkan latar belakang diatas, masalah peneltian ini dapat dirumuskan, sejauhmana tingkat kompetensi professional, pedagogik, kepribadian dan sosial guru $\mathrm{RA} / \mathrm{BA}$ di enam kab./ kota di Indonesia?

\section{Tujuan}

Tujuan dari penelitian ini adalah untuk mengetahui sejauhmana tingkat kompetensi guru Radlotul Athfal (RA)/BA di enam kota di Indonesia, yang mencakup: kompetensi pedagogik, kompetensi kepribadian, kompetensi sosial dan kompetensi profesional.

\section{Definisi Konseptual}

\section{a. Kompetensi Gurn}

Kompetensi diartikan sebagai pemilikan, penguasaan, keterampilan dan kemampuan yang dituntut oleh jabatan seseorang. Dalam menjalankan kewenangan profesionalnya seorang guru dituntut memiliki kemampuan kognitif, afektif dan psikhomotorik. ${ }^{2}$ Menurut UU nomor 14 Tahun 2005 pada Bab I pasal 1 ayat 10, disebutkan bahwa kompetensi dimaksukan sebagai seperangkat pengetahuan, ketrampilan dan prilaku yang harus dimiliki, dihayati, dan dikuasai oleh guru atau dosen dalam melaksanakan tugas keprofesionalan. Dengan demikian kompetensi dapat diberi makna sebagai seorang yang memiliki kemampuan, keahlian, kewenangan, keterampilan, pengetahuan yang diperlukan untuk melakukan suatu tugas tertentu.

Dalam PP Nomor 19 Tahun 2005 tentang Standar Nasional Pendidikan pada Bab VI pasal 28 ayat 3 menyebutkan bahwa kompetensi sebagai agen pembelajaran pada jenjang pendidikan dasar dan menengah serta pendidikan anak usia dini meliputi: kompetensi pedagogik, kompetensi kepribadian, kompetensi profesional dan kompetensi sosial. ${ }^{3}$

Dalam penelitian ini yang dimaksud dengan kompetensi adalah kewenangan, pengetahuan, kemampuan, yang harus dimiliki oleh guru Raudlatul Athfal (RA)/BA untuk melaksanakan tugasnya sebagai guru

${ }^{2}$ Muhibuddin Syah, Psychologi Pendidikan; Suatu pendekatan Baru. Bandung: Remaja RosdaKarya, h. 230.

3 PP Nomor 19 Tahun 2005 tentang Standar Nasional Pendidikan 
RA baik kompetensi profesional, kompetensi paedagogik, kompetensi personal dan kompetensi sosial.

Kompetensi profesional menurut Suharini (1990) adalah kemampuan guru dalam penguasaan akademik yang diajarkan serta kemampuan mengajarkannya. Menurut penjelasan UU No. 14 tahun 2005 pasal 10 ayat 1 menyebutkan bahwa yang dimaksud dengan kompetensi profesional adalah kemampuan penguasaan materi pelajaran secara luas dan mendalam. Kompetensi profesional guru RA dalam penelitian ini adalah pemilikan kewenangan, pengetahuan, dan kemampuan yang berkaitan dengan penguasaan materi pelajaran, meliput; Akhlak Prilaku, Agama Islam, Bahasa, Kognitif, Fisik/Motorik, Seni di Raudlotul Athfal secara luas dan mendalam.

Kompetensi pedagogik menurut UU Nomor 14 Tahun 2005 adalah kemampuan guru dalam pengelolaan pembelajaran peserta didik ${ }^{4}$, kemampuan ini sekurang-kurangnya meliput: pemahaman wawasan atau landasan kependidikan; pemahaman terhadap peserta didik; pengembangan kurikulum; perencanaan pembelajaran; pelaksanaan pembelajaran yang mendidik dan dialogis, pemanfaatan teknologi pembelajaran; evaluasi hasil belajar; dan pengembangan peserta didik untuk mengaktualisasaikan berbagai potensi yang dimilkinya.

Kompetensi kepribadian guru adalah kemampuan guru untuk memiliki sikap kepribadian yang mantap, yakni ia memiliki kepribadian yang patut diteladani. ${ }^{5}$ Sukmadinata merinci kompetensi personal menjadi tiga cakupan, yakni : (a). penampilan sikap positif terhadap keseluruhan tugasnya sebagai guru dan terhadap keseluruhan situasi pendidikan; (b). pemahaman, penghayatan, dan penampilan nilainilai yang seyogyanya dimiliki guru (c). penampilan sebagai upaya untuk menjadikan dirinya sebagai panutan dan teladan bagi siswanya. ${ }^{6} \mathrm{Jadi}$ kompetensi kepribadian guru RA dalam penelitian adalah pemilikan wewenang, pengetahuan dan sikap seorang guru RA sebagai pribadi yang mantap dan positif yang patut diteladani dari seorang guru sesuai dengan ajaran Islam.

Kompetensi sosial guru adalah kemampuan guru dalam berkomuni-

${ }^{4}$ Trianto dkk: 2007. Sertifikasi Guru dan Upaya Peningkatan Kualifikasi, Kompetensi dan Kesejahteraan, Jakarta: Prestasi Pustaka, Cet. 1., h. 233

${ }^{5}$ Suharsini Arikunto. 1990. Manajemen Pengajaran Manusiawi. Jakarta: Rineka Cipta.

'Sukmadinata. 2000. Pengembangan Kurikulum: Teori dan Praktek. Bandung: Remaja Rosda Karya, hh. 192 
kasi dengaan para siswa, guru, kepala sekolah, pegawai tata usaha, anggota masyarakat di lingkungannya. ${ }^{7}$ Sukmadinata memaknai kompetensi sosial sebagai kemampuan menyesuaikan diri dengan tuntutan kerja dan lingkungan sekitar. ${ }^{8}$ Sedangkan UU Guru dan Dosen menyebutkan bahwa kompetensi sosial adalah kemampuan guru untuk berkomunikasi dan berinteraksi secara efektif dan efisien dengan peserta didik, sesama guru, orangtua/wali peserta didik, dan masyarakat sekitat. Dari definisi tersebut dapat ditarik kesimpulan bahwa kompetensi sosial adalah kemampuan untuk berhubungaan dengan siswa, guru, pegawai tata usaha, kepala sekolah dan masyarakat. kompetensi sosial yang dimaksud dalam penelitian ini adalah kepemilikan wewenang, pengetahuan, dan kemapuan seorang guru RA/BA untuk berhubungan dengan siswa, sesama guru, pegawai tata usaha, kepala sekolah, serta masyarakat di lingkungan sekolah dan tempat tinggalnya.

\section{b. Pendidikan Anak Usia Dini (PAUD)}

Pendidikan anak usia dini merupakan pendidikan yang ditujukan bagi anak-anak usia pra sekolah agar dapat

${ }^{7}$ Suharsimi, op. cit, hal. 239

${ }^{8}$ Sukmadinata. op.cit. h. 192 mengembangkan potensinya sejak dini sehingga anak-anak tersebut dapat berkembang secara wajar sebagai anak. Bahkan, pendidikan anak usia dini tidak hanya mengharapkan agar anakanak lebih siap belajar di sekolah dasar, tetapi lebih jauh dari itu, anak diharapkan sejak dini mendapat rangsangan inteletual, sosial dan emosional sesuai dengan tingkat perkembangan usianya.

UU No. 20/2003 tentang Sisdiknas pasal 1 ayat (14) menyatakan bahwa, Pendidikan anak usia dini adalah suatu upaya pembinaan yang ditujukan kepada anak sejak lahir sampai dengan usia enam tahun yang dilakukan melalui pemberian rangsangan pendidikan untuk membantu pertumbuhan dan perkembangan jasmani dan rohani agar anak memiliki kesiapan dalam memasuki pendidikan lebih lanjut. Sedangkan jalur pendidikan usia dini meliputi pendidikan formal, nonformal dan informal. Pendidikan formal berbentuk Taman Kanak-Kanak (TK), RA/ BA atau sederajat, jalur pendidikan nonformal berbentuk Tempat Penitipan Anak (TPA), Kelompok Bermain (KB) atau sederajat, sedangkan jalur pendidikan informal berbentuk pendidikan keluarga atau pendidikan yang diselenggarakan oleh lingkungan (Pasal 28) 
Roudlatul Athfal (RA) adalah salah satu bentuk pendidikan anak usia dini pada jalur pendidikan formal yang menyelenggarakan program pendidikan umum dan pendidikan keagamaan Islam bagi anak berusia empat tahun sampai berusia enam tahun sampai memasuki lembaga pendidikan dasar (Madrasah Ibtidaiyah atau Sekolah Dasar). Berdasarkan data Statistik Pendidikan Agama dan Keagamaan Departemen Agama RI Tahun 20052006 jumlah RA/BA sebanyak 18.413 lembaga, dengan jumlah siswa sebanyak 682.407 siswa, kemudian jumlah tenaga pengajar/guru sebanyak 65.419 orang terdiri dari 6.752 guru PNS, dan 58.667 non-PNS.

\section{E. Definisi Operasional}

\section{a. Kompetensi Profesional}

Kompetensi profesional guru secara operasional merupakan skor total dari hasil pengisian instrumen yang berkaitan dengan penguasaan materi pelajaran yang diajarkan. Dimensinya meliputi penguasaan materi Akhlak Prilaku, Agama Islam, Bahasa, Kognitif Fisik/Motorik dan Seni.

\section{b. Kompetensi Pedagogik}

Kompetensi pedagogik guru secara operasional merupakan skor total dari hasil pengisian instrumen yang betkaitan dengan kemampuan dalam pengelolaan pembelajaran peserta didik. Dimensinya meliputi a) pemahaman wawasan/landasan kependidikan, b) pemahamaan terhadap siswa, c) pengembangan kurikulum, d) perencanaan pembelajaran, e) metode pembelajaran, $f$ ) media pembelajaaran, g) evaluasi, dan $\mathrm{h}$ ) pengembangan bakat siswa

\section{c. Kompetensi Kepribadian}

Kompetensi kepribadian guru secara operasional merupakan skor total dari hasil pengisian instrumen kompetensi kepribadian. Dimensinya adalah a) minat dan sikap positif terhadap profesi guru, b) motivasi berprestasi, dan c) sikap yang diteladani.

\section{d. Kompetensi Sosial.}

Kompetensi sosial guru secara operasional merupakan skor total dari hasil pengisian instrumen kompetensi sosial. Dimensinya yaitu kemampuan berhubungan baik dengan a) siswa, b) kepala sekolah, c) sesama guru, d) pegawai tata usaha, e) keluarga dan f) masyarakat.

\section{F. Metodologi}

\section{Lokasi}

Penelitian dilaksanakan di 6 (enam) kota/kabupaten, yaitu: Batam, Yogyakarta, Balikpapan, Denpasar, Mataram dan Gotontalo. 


\section{Metode Penelitian}

Penelitian ini menggunakan pendekatan kuantitatif, dengan teknik analisis deskriptif statistik.

\section{Populasi dan Sampel}

Populasi target penelitian ini adalah seluruh guru Raudlotul Athfal/ Bustanul Athfal yang terdapat di 6 wilayah penelitian. Sedangkan teknik penentuan sampel dilakukan secara purposive sampling, dengan cara, pertama, menentukan 6 wilayah sasaran penelitian, kemudian dari masing-masing wilayah dipilih satu lokasi sasaran berdasarkan jumlah guru RA/BA terbanyak di propinsi. Dari setiap kota / kabupaten diambil 10 lembaga RA/BA. Kemudian dari setiap RA/BA dipilih 3 guru berdasarkan masa kerja guru minimal dua tahun dan pendidikan minimal SMA/ MA. Jumlah keseluruhan responden sebanyak 180 guru.

\section{Instrumen Penelitian}

Instrumen yang digunakan dalam penelitian ini adalah berupa tes dan kuesioner. Untuk mengetahui kompetensi profesional dan pedagogik guru RA digunakan tes. Sedangkan kuesioner digunakan untuk menjaring data kompetensi kepribadian dan kompetensi sosial.

\section{Teknik Pengumpulan Data}

Dalam penelitian ini, pengumpulan data dilakukan dengan menggunakan tes sebanyak dua paket dan kuesioner sebanyak dua paket. Tes digunakan untuk mengumpulkan data tentang kompetensi profesional dan pedagogik. Sedang Kuesioner digunakan untuk mengumpulkan data tentang kompetensi kepribadian dan kompetensi sosial.

\section{Teknik Analisa Data}

Analisis data penelitian menggunakan teknik statistik deskiptif, yaitu untuk mendiskripsikan variabel penelitian yang diperoleh melalui hasil pengukuran.

Untuk melakukan penafsiran secara kualitatif, maka perlu ditetapkan katagori skor menjadi:

Skor $85-100=$ bernilai sangat baik (A) Skor 70-84,5 = bernilai baik (B) Skor $60-69,5=$ bernilai sedang $(C)$ Skor $<60=$ bernilai kurang (D)

\section{HASIL PENELITIAN DAN PEMBAHASAN}

\section{A. Profil Responden}

Jumlah guru RA/BA yang menjadi responden penelitian sebanyak 176 orang, dan seluruhnya perempuan. Hal ini menunjukan mayoritas tenaga pengajar di RA adalah perempuan, 
karena memang dunia anak-anak lebih dekat pada ibu-ibu bila dibandingkan guru laki-laki. Dari segi usia, mayoritas berusia antara 31 - 40 tahun yakni $42,6 \%$, sedangkan lainnya $38,6 \%$ berusia antara $21-30$ tahun, 11,4 $\%$ berusia antara $41-50$ tahun, 6,8 $\%$ berusia antara $51-60$ tahun, dan ada $0,6 \%$ dari responden yang masih berusia di bawah 20 tahun.

Status kepegawaian sebagian besar responden guru $\mathrm{RA} / \mathrm{BA}$ adalah non PNS yaitu sebanyak $81,8 \%$ dan $18,2 \%$ adalah PNS. Hal ini, menunjukan bahwa seluruh lembaga RA/ BA dibangun dan dikelola oleh masyarakat dan belum ada yang berstatus negeri.

Berdasarkan jumlah responden yang telah bekerja di RA/BA lebih dari 10 tahun sebesar 18,2\% (32 responden) sedangkan yang bekerja kurang dari 10 tahun sebanyak 144 responden $(81,8 \%)$. Frekuensi responden mengikuti latihan, sebanyak 72,2 $\%$ responden sudah pernah mengikuti pelatihan, baik dari Depertemen Agama maupun Departemen Pendidikan Nasional. Sedangkan yang belum pernah mengikuti pelatihan sebanyak $27,8 \%$ (49 responden).

\section{B. Kompetensi Profesional}

Kompetensi profesional guru $\mathrm{RA} / \mathrm{BA}$ ini adalah pemilikan kewe- nangan, pengetahuan, dan kemampuan seorang guru yang berkaitan dengan penguasaan materi pelajaran yang meliput; Akhlak Prilaku, Agama Islam, Bahasa, Kognitif, Fisik/ Motorik, Seni di Raudlotul Athfal secara luas dan mendalam

Table 1. Perolehan Skor Kompetensi

Profesional Berdasarkan wilayah

\begin{tabular}{|c|l|c|c|c|l|}
\hline No. & Wilayah & $\Sigma$ & Rerata & $\%$ & Tafsiran \\
\hline 1. & Batam & 28 & 27.18 & 67.95 & Sedang \\
\hline 2. & Balikpapan & 32 & 28.53 & 71.33 & Baik \\
\hline 3. & Mataram & 31 & 27.26 & 68.15 & Sedang \\
\hline 4. & Yogyakarta & 30 & 29.47 & 73.67 & Baik \\
\hline 5. & Gorontalo & 29 & 25.21 & 63.02 & Sedang \\
\hline 6. & Denpasar & 26 & 30.46 & 76.15 & Baik \\
\hline & Jumlah & 176 & 27.99 & 69.97 & Sedang \\
\hline
\end{tabular}

Sumber: Pengolahan Data Primer 2007

Berdasarkan data diatas, menunjukkan bahwa hasil uji kompetensi profesional guru RA/BA rata-rata dari 6 daetah kota/kabupaten tergolong kategori sedang, dengan retata jawaban responden yang benar sebesar 27,99. Namun apabila di lihat pada masingmasing daerah ada 3 daerah yang memiliki kompetensi profesionalnya tergolong baik yaitu Kota Balikpapan, Kota Yogyakarta dan kota Denpasar. Sedangkan kota Batam, kota Mataram dan Kota Gorontalo memiliki kompetensi professional termasuk dalam kategori sedang.

Selanjutnya, tingkat kompetensi professional guru RA/BA berdasarkan status kepegawaiannya. Hasilnya 
menujukkan rata-rata tingkat kompetensi professional pegawai yang non PNS lebih tinggi yaitu sebesar 28,03 dibandingkan tingkat kompetensi professional pegawai yang telah berstatus PNS hanya 27,78.

Tingkat kompetensi guru RA/ BA berdasarkan masa kerjanya, diperoleh data bahwa nilai rata-rata guru yang telah bekerja lebih dari 10 tahun lebih tinggi dari guru yang masa kerjanya dibwah 10 tahun. Guru yang telah bekerja selama lebih dari 10 tahun memiliki nilai rata-rata 28,50 sedangkan guru yang bekerja kurang dari 10 tahun memiliki nilai sebesar 27,88.

Berdasarkan usia guru, menujukkan bahwa tingkat kompetensi profesional yang berusia diatas 40 tahun tahun lebih tinggi dari guru yang berusia dibawah 40 tahun. Rata-rata nilai guru yang berusia diatas 40 tahun adalah 27,3 , sedangkan guru yang berusia di bawah 40 tahun adalah 28,31. Selanjutnya berdasarkan tingkat pendidikan guru, dikelompokkan menjadi 2 kategori, yaitu pendidikan tarbiyah dan non tarbiyah. Tarbiyah diartikan menempuh sekolah keagamaan dan non tarbiyah diartikan menempuh sekolah umum. Setelah itu dibagi lagi menjadi dua bagian PGTK dan Non PGTK (SMU/SMK/MA, DI DII, DIII dan S1). Maka diperoleh data bahwa tingkat kompetensi guru yang paling tinggi berada terpadat pada guru yang pendidikan tingginya berasal dari tarbiyah namun tidak lulusan PGTK yaitu sebesar 29,05. Diikuti guru yang berasal dari pendidikan non tarbiyah dan mem-punyai spesifikasi menamatkan PGTK, dengan nilai rata-rata 29,18. Selanjutnya guru non tarbiyah dan non PGTK dengan nilai rata-rata 27,38 dan yang terakhir guru yang pendidikan tarbiyah dan mempunyai pendidikan tinggi PGTK. Dapat dilihat pada tabel berikut:

Table 2. Data Tingkat Kompetensi Profesional Guru RA/BA Berdasarkan

Pendidikan Tinggi Tarbiyah \& Non Tarbiyah

\begin{tabular}{|l|c|c|c|c|}
\hline \multirow{2}{*}{ Deskripsi Data } & \multicolumn{3}{|c|}{ Pendidikan Profesi } \\
\cline { 2 - 5 } & \multicolumn{2}{|c|}{ Tarbiyah } & \multicolumn{2}{c|}{ Non Tarbiyah } \\
\cline { 2 - 5 } & PGTK & $\begin{array}{c}\text { Non } \\
\text { PGTK }\end{array}$ & PGTK & $\begin{array}{c}\text { Non } \\
\text { PGTK }\end{array}$ \\
\hline Mean & 27.27 & 29.05 & 28.18 & 27.38 \\
\hline Standar Deviasi & 4.384 & 3.346 & 3.361 & 3.852 \\
\hline $\begin{array}{l}\text { Jumlah } \\
\text { Responden }\end{array}$ & 11 & 41 & 50 & 74 \\
\hline $\begin{array}{l}\text { Jumlah } \\
\text { responden total }\end{array}$ & \multicolumn{4}{|c|}{176} \\
\hline Mean Total & \multicolumn{4}{|c|}{27.99} \\
\hline $\begin{array}{l}\text { Standar Deviasi } \\
\text { Total }\end{array}$ & \multicolumn{4}{|c|}{3.671} \\
\hline
\end{tabular}

Sumber: Pengolahan Data Primer, 2007

Sedangkan tingkat kompetensi. profesional guru RA/BA berdasarkan keikutsertaan dalam pelatihan, menunjukan lebih baik bila dibandingkan guru yang tidak pernah mengikutinya. Nilai rata-rata untuk yang pernah mengikuti pelatihan adalah 28,46 . Se- 
dangkạn nilai rata-rata untuk yang tidak pernah mengikuti adalah 26,76 .

\section{Kompetensi Pedagogik}

Kompetensi pedagogik guru RA/ BA adalah kemampuan guru dalam pengelolaan pembelajaran peserta didik, kemampuan ini meliputi dalam hal: pemahaman wawasan atau landasan kependidikan; pemahaman terhadap peserta didik; pengembangan kurikulum; perencanaan pembelajaran; pelaksanaan pembelajaran yang mendidik dan dialogis, pemanfaatan teknologi pembelajaran; evaluasi hasil belajar; dan pengembangan peserta didik untuk mengaktualisasaikan berbagai potensi yang dimillkinya.

Tabel 3. Perolehan Skor Tingkat Kompetensi Pedagogik Berdasarkan Wilayah

\begin{tabular}{|l|l|c|c|c|l|}
\hline No. & Wilayah & $\Sigma$ & Rerata & $\%$ & Tafsiran \\
\hline 1. & Batam & 28 & 25,21 & 63,04 & Sedang \\
\hline 2. & Balikpapan & 32 & 27,34 & 68,36 & Sedang \\
\hline 3. & Mataram & 31 & 24,58 & 61,45 & Sedang \\
\hline 4. & Yogyakarta & 30 & 27,43 & 68,58 & Sedang \\
\hline 5. & Gorontalo & 29 & 24,69 & 61,72 & Sedang \\
\hline 6. & Denpasar & 26 & 23,92 & 59,81 & Kurang \\
\hline & Jumlah & 176 & 25,53 & 63,83 & Sedang \\
\hline
\end{tabular}

Berdasarkan data diatas, menunjukkan bahwa hasil uji kompetensi pedagogik guru RA/BA rata-rata dari 6 daerah kota/kabupaten tergolong kategori sedang, dengan rerata jawaban responden yang benar sebesar 25,53.

Skor tertinggi yang diperoleh adalah $68,58 \%$ dari 40 butir soal de- ngan rerata 27,43 dari 30 orang responden (Yogyakarta) dan skor terendah adalah 59,81\% dari 40 butir soal dengan rerata 23, 92 dari 26 orang responden (Denpasar). Dari 6 wilayah yang menjadi lokasi penelitian diperoleh urutan skor tingkat kompetensi pedagogik dari yang terendah sampai yang tertinggi sebagai berikut, yaitu: Denpasar, Mataram, Gorontalo, Batam, Balikpapan dan Yogyakarta.

Hasil uji kompetensi pedagogik guru RA/BA berdasarkan ststus pegawai menunjukan bahwa guru non PNS lebih besar yaitu 25,58 dibandingkan guru RA/BA yang berstatus PNS yaitu 25,66. Sedangkan berdasarkan masa kerjanya, tingkat kompetensi pedagogik guru RA/BA yang telah bekerja kurang dari 10 tahun lebih tinggi dari guru yang masa kerjanya diatas 10 tahun. Guru yang telah bekerja selama kurang dari 10 tahun memiliki nilai rata-rata 25,78 sedangkan guru yang bekerja lebih dari 10 tahun memiliki nilai sebesar 24,75.

Selanjutnya dilihat dari usia guru, tingkat kompetensi pedagogik guru RA/BA dibawah umur 40 tahun lebih tinggi dari guru yang berusia diatas 40 tahun. Rata-rata nilai guru yang berusia dibawah 40 tahun adalah 25,86 sedangkan guru yang berusia diatas 40 tahun 24,24. 
Berdasarkan tingkat pendidikan guru RA/BA bervariasi, dikelompokkan 2 kategori, yaitu pendidikan tarbiyah dan non tarbiyah. Tarbiyah diartikan menempuh sekolah keagamaan dan non tarbiyah diartikan sekolah umum. Setelah itu dibagi lagi menjadi dua bagian PGTK dan Non PGTK (SMU/SMK/MA, DI DII, DIII dan S1). Diperoleh data bahwa tingkat kompetensi guru yang paling tinggi terdapat pada guru yang pendidikannya berasal dari non tarbiyah namun tidak lulusan PGTK yaitu sebesar 25,95. Diikuti guru yang berasal dari pendidikan tarbiyah dan menamatkan PGTK dengan nilai rata-rata 25,94. Selanjutnya guru non tarbiyah yang menamatkan PGTK dengan nilai rata-rata 25,91 dan yang terakhir guru yang pendidikan tarbiyah namun tidak lulusan PGTK dengan nilai rata-rata 25,11. Dapat dilihat pada tabel 4

Tabel 4. Data Tingkat Kompetensi Pedagogik Guru RA/BA Berdasarkan

Pendidikan Tarbiyah dan Non Tarbiyah

\begin{tabular}{|l|c|c|c|c|}
\hline \multirow{2}{*}{ Deskripsi Data } & \multicolumn{4}{|c|}{ Pendidikan Profesi } \\
\cline { 2 - 5 } & \multicolumn{2}{|c|}{ Tarbiyah } & \multicolumn{2}{c|}{ Non Tarbiyah } \\
\cline { 2 - 5 } & PGTK & $\begin{array}{c}\text { Non } \\
\text { PGTK }\end{array}$ & PGTK & $\begin{array}{c}\text { Non } \\
\text { PGTK }\end{array}$ \\
\hline Mean & 25,94 & 25,11 & 25,91 & 25,95 \\
\hline Standar Deviasi & 3,683 & 4,895 & 4,700 & 4,421 \\
\hline $\begin{array}{l}\text { Jumlah } \\
\text { Responden }\end{array}$ & 50 & 74 & 11 & 41 \\
\hline $\begin{array}{l}\text { Jumlah } \\
\text { responden total }\end{array}$ & \multicolumn{4}{|c|}{176} \\
\hline Mean Total & \multicolumn{4}{|c|}{25,59} \\
\hline $\begin{array}{l}\text { Standar Deviasi } \\
\text { Total }\end{array}$ & \multicolumn{5}{|c|}{4,438} \\
\hline
\end{tabular}

Selanjutnya berdasarkan frekuensi pelatihan guru $\mathrm{RA} / \mathrm{BA}$, hasil uji kompetensi profesional yang pernah mengikuti pelatihan baik dari Departemen Agama maupun Departemen Pendidikan Nasional menunujukkan lebih baik dibandingkan yang tidak pernah mengikuti pelatihan. Nilai ratarata untuk yang pernah mengikuti pelatihan adalah 25.81. Sedangkan nilai rata-rata untuk yang tidak pernah mengikuti pelatihan adalah 25.02 .

\section{D.Tingkat Kompetensi \\ Kepribadian}

Deskripsi data ini menyajikan keadaan data masing-masing variabel penelitian, seperti skor rata-rata (mean) dan tingkat pencapaian responden masing-masing variabel penelitian dengan menggunakan analisis skor ideal, yaitu perbandingan skor ratarata dengan skor maksimal masingmasing variabel.

Tingkat pencapaian responden pada masing-masing variabel dan butir menggunakan analisis nilai skor ideal dengan menggunakan rumus :

Skor Rata-rata

Skor Nilai Ideal $=\longrightarrow \times 100 \%$

Skor Maksimum

Dengan pengkategorian nilai pencapaian responden digunakan klasifikasi menurut Sudjana (2002) sebagai berikut : 
$90 \%-100 \%$ Sangat Baik

$80 \%-89 \%$ Baik

$65 \%-79 \%$ Cukup

$55 \%-64 \%$ Kurang Baik

$0 \%-54 \% \quad$ Tidak Baik

\section{Minat dan Sikap Positif terbadap}

profesi gum

Berdasarkan hasil analisis data tang kompetensi kepribadian dilihat i variabel minat dan sikap positif hadap profesi guru secara keseluan termasuk dalam kategori baik ngan rata-tata 4,28 (85,68\%). Ini enunjukan bahwa kompetensi pribadian yang berkaitan dengan nat dan sikap positif terhadap guru RA sasaran penelitian mendekati al. Secara umum guru-guru RA miliki motivasi yang kuat dalam endidik anak-anak didiknya, walaun keterbatasan kesejahteraan mereka.

Beberapa aspek yang tergolong tegori sangat baik adalah butir (a) erasa senang menjadi guru, (b) ngga menjadi guru, (c) menjadi guru ak sekedar mencari pengalaman, tidak merasa malu menjadi guru, memilih jadi guru bukan karena sekolah banyak waktu libur, (f) emilih guru bukan hanya karena lak adanya pekerjaan lain, (g) tidak erasa terpaksa menjadi guru, (h) rupaya mengenali anak didik.

Aspek materi tergolong baik alah butir (a) merasa ada beban ketika tidak masuk kesekolah, (b) sudah bercita-cita menjadi guru dari kecil, (c) senang mendiskusikan kemajuan anak didik, (d) befikir dua kali jika ada pekerjaan selain guru, (e) menjadi guru memberikan ketenangan batin, (f) mengajar tidak merupakan pekerjaan yang melelahkan, (g) membuat persiapan mengajar sebelum mengajar.

Aspek materi yang tergolong cukup baik adalah butir (a) berat memohon izin meninggalkan mengajar, (b) tetap berusaha megajar walaupun keadaan sakit, (c) tidak tertarik dengan bisnis diluar jam mengajar. Sedangkan beberapa aspek yang tergolong kurang baik adalah butir menjadi guru karena dorongan dari orang tua.

\section{b. Motivasi Berprestasi}

Berdasarkan hasil analisis data tentang kompetensi kepribadian dilihat dari variabel motivasi berprestasi guru RA/BA tergolong kategori cukup baik dengan rata-rata $3,53(70,64 \%)$. Ini menujnukan motivasi berprestasiguru RA/BA belum diharapkan secara maksimal, karena itu perlu ditingkatkan

Beberapa aspek yang tergolong sangat baik adalah butir (a) berusaha mencapai tujuan pembelajaran yang telah ditetapkan, (b) menyusun rencana pembelajaran secara matang se- 
Berdasarkan tingkat pendidikan u RA/BA bervariasi, dikelompok2 kategori, yaitu pendidikan tarah dan non tarbiyah. Tarbiyah dikan menempuh sekolah keagamadan non tarbiyah diartikan sekolah um. Setelah itu dibagi lagi menjadi bagian PGTK dan Non PGTK UU/SMK/MA, DI DII, DIII dan . Diperoleh data bahwa tingkat npetensi guru yang paling tinggi lapat pada guru yang pendidikannya asal dari non tarbiyah namun tidak usan PGTK yaitu sebesar 25,95. kuti guru yang berasal dari pendiditarbiyah dan menamatkan PGTK igan nilai rata-rata 25,94 . Selanjutguru non tarbiyah yang menamatPGTK dengan nilai rata-rata 25,91 yang terakhir guru yang pendidit tarbiyah namun tidak lulusan TK dengan nilai rata-rata 25,11. pat dilihat pada tabel 4

Tabel 4. Data Tingkat Kompetensi Pedagogik Guru RA/BA Berdasarkan endidikan Tarbiyah dan Non Tarbiyah

\begin{tabular}{|c|c|c|c|c|}
\hline \multirow{3}{*}{ kripsi Data } & \multicolumn{4}{|c|}{ Pendidikan Profesi } \\
\hline & \multicolumn{2}{|c|}{ Tarbiyah } & \multicolumn{2}{|c|}{ Non Tarbiyah } \\
\hline & PGTK & $\begin{array}{l}\text { Non } \\
\text { PGTK }\end{array}$ & PGTK & $\begin{array}{l}\text { Non } \\
\text { PGTK }\end{array}$ \\
\hline$n$ & 25,94 & 25,11 & 25,91 & 25,95 \\
\hline Idar Deviasi & 3,683 & 4,895 & 4,700 & 4,421 \\
\hline $\begin{array}{l}\text { lah } \\
\text { ponden }\end{array}$ & 50 & 74 & 11 & 41 \\
\hline lah & \multicolumn{4}{|c|}{176} \\
\hline in Total & \multicolumn{4}{|c|}{25,59} \\
\hline idar Deviasi & \multicolumn{4}{|c|}{4,438} \\
\hline
\end{tabular}

Selanjutnya berdasarkan frekuensi pelatihan guru RA/BA, hasil uji kompetensi profesional yang pernah mengikuti pelatihan baik dari Departemen Agama maupun Departemen Pendidikan Nasional menunujukkan lebih baik dibandingkan yang tidak pernah mengikuti pelatihan. Nilai ratarata untuk yang pernah mengikuti pelatihan adalah 25.81. Sedangkan nilai rata-rata untuk yang tidak pernah mengikuti pelatihan adalah 25.02 .

\section{D.Tingkat Kompetensi \\ Kepribadian}

Deskripsi data ini menyajikan keadaan data masing-masing variabel penelitian, seperti skor rata-rata (mean) dan tingkat pencapaian responden masing-masing variabel penelitian dengan menggunakan analisis skor ideal, yaitu perbandingan skor ratarata dengan skor maksimal masingmasing variabel.

Tingkat pencapaian responden pada masing-masing variabel dan butir menggunakan analisis nilai skor ideal dengan menggunakan rumus :

Skor Rata-rata

Skor Nilai Ideal $=\longrightarrow \times 100 \%$

Skor Maksimum

Dengan pengkategorian nilai pencapaian responden digunakan klasifikasi menurut Sudjana (2002) sebagai berikut : 
belum dilaksanakan, (c) mengerjakan tugas-tugas sesuai dengan prosedur yang berlaku, (d) menjalankan amanah yang telah dipercayakan. Aspek tergolong baik adalah butir (a) merasa ada beban ketika tidak masuk kesekolah, (b) sudah bercita-cita menjadi guru dari kecil, (c) senang mendiskusikan kemajuan anak didik, (d) befikir dua kali jika ada pekerjaan selain guru, (e) menjadi guru memberikan ketenangan batin, ( $f$ ) mengajar tidak merupakan pekerjaan yang melelahkan, (g) membuat persiapan mengajar sebelum mengajar.

Beberapa aspek yang termasuk kategori cukup baik adalah butir (a) berusaha mencapai sukses agar menjadi panutan bagi teman sejawat, (b) berusaha memberikan ide-ide yang rasional dalam rapat, (c) berusaha memberikan peran terbaik dalam setiap kegiatan.

\section{c. Sikap yang diteladani}

Berdasarkan hasil analisis data tentang kompetensi kepribadian dilihat dari sikap yang diteladani secara keseluruhan tergolong kategori baik dengan rata-rata 4,31 $(86,15 \%)$. Beberapa aspek yang tergolong sangat baik adalah butir (a) tidak setuju bahwa seorang muslim yang sudah menunaikan zakat tidak perlu lagi memberikan infaq terhadap pernyataan tersebut, (b) tidak setuju jika ada orang yang tidak mau memberi maaf, (c) bila ada musibah menyadari hal itu sebagai ujian dari Allah SWT, (d) menanggapi orang yang selalu berpuasa sunat, berusaha untuk mengikutinya, (e) sering melakukan zikir kepada Allah, (f) zikir dapat menentramkan hati. Aspek materi tergolong baik adalah butir (a) memberikan infaq dan sadaqah tanpa diketahui orang lain, (b) ingin betgabung dengan temanteman yang rajin menghafal al quran. Sedangkan aspek materi yang tergolong cukup baik adalah butir (a) saya hanya dapat betkosentrasi sesaat.

\section{E. Tingkat Kompetensi Sosial}

\section{a. Hubungan guru di lingkungan Raudbatul Atbfal}

Berdasarkan hasil analisis data tentang kompetensi sosial yaitu hubungan guru di lingkungan RA dilihat dari masing-masing butir dapat dijelaskan bahwa secara keseluruhan variabel hubungan guru di lingkungan sekolah adalah tergolong kategori Baik dengan rata-rata 4,05 (81,07\%). Artinya komunikasi guru RA/BA mendekati ideal. Beberapa aspek yang tergolong sangat baik adalah butir rekan kerja selalu berkunjung ketika saya sakit. (b) mudah mendapatkan teman diskusi di tempat kerja, (c) saatsaat tertentu saya bersilaturahmi ke rumah kepala sekolah. Bebrapa aspek 
yang tergolong baik adalah butir (a) dilibatkan dalam suatu kegiatan di tempat kerja, (b) betkomunikasi dengan orang tua murid yang anaknya bermasalah, (c) banyak siswa yang menanyakan ketika saya masuk, (d) tidak pernah kurang menyukai pengawas pendidikan, (e) merasa senang berdiskusi dengan teman sejawat, $(f)$ tidak setuju bahwa berbicara dengan orang yang tidak seprofesi kurang bermanfaat, $(\mathrm{g})$ berkonsultasi dengan komite dalam membicarakan kemajuan sekolah. Aspek yang tergolong cukup baik adalah butir (a) tidak nyaman ketika rekan kerja terlalu dekat secara emosional, (b) punya teman yang dapat diandalkan dalam masamasa sulit, (c) ragu pada teman kerja apakah peduli pada saya. Sedangkan beberapa aspek yang tergolong kurang baik adalah butir (a) mengadu pada kepala sekolah jika menghadapi masalah.

\section{b. Hubungan dengan masyarakat sekitar tempat tinggal}

Secara keseluruhan variabel hubungan guru di lingkungan masyarakat tempat tinggal adalah tergolong kategori cukup baik dengan rata-tata $3,78(75,64 \%)$. Ini berarti kompetensi kepribadian yang terkait dengan hubungan dengan masyarakat sekitar perlu ditingkatkan.
Aspek-aspek yang mencapai kategori sangat baik adalah butir (a) tetangga membantu ketika saya mengadakan suatu acara di rumah, (b) mengenal masyarakat disekitar sekolah, (c) tidak memiliki orang yang tidak akan dimaafkan, (d) menjadi panutan bagi masyarakat dilingkungan tempat tinggal, (e) hubungan dengan anak-anak sekitar sangat baik. Aspek kategori baik adalah butir (a) mengikuti rapat dilingkungan RT, (b) berpendapat, bahwa masyarakat disekitar sekolah ramah sekali, (c) kenal dengan tokoh-tokoh masyarakat di sekitar sekolah, (d) senang mengikuti berbagai kegiatan disekitar tempat tinggal. Aspek cukup baik adalah butir (a) secara berkala aktif mengikuti kegiatan sosial dilingkungan tempat tinggal, (b) menjadi paniitia pada hari besar Islam di lingkungan sekolah. Sedangkan aspek yang tergolong tidak baik adalah butir (a) tidak ikut mempelopori kegiatan olah raga di masyarakat, (b) tidak ikut dalam kepengurusan mesjid, (c) tidak terlibat di kepengurusan RT.

\section{c. Hubungan dengan Keluarga}

Berdasarkan hasil analisis data tentang kompetensi sosial yakni pada hubungan dengan keluarga dilihat dari masing-masing butir dapat dijelaskan sebagai berikut : 
Table 24. Deskripsi Data kompetensi kepribadian guru RA/BA dilihat dari sikap-sikap yang diteladani.

\begin{tabular}{|c|c|c|c|c|c|c|c|c|c|}
\hline \multirow{2}{*}{$\begin{array}{c}\text { Butir } \\
\text { Soal }\end{array}$} & \multicolumn{4}{|c|}{ Kriteria Jawaban } & \multirow{2}{*}{$\begin{array}{c}\text { Jumlah } \\
\text { Responden }\end{array}$} & $\begin{array}{c}\text { Rata- } \\
\text { rata }\end{array}$ & $\%$ & Kesimpulan \\
\hline 20 & 106 & 37 & 8 & 15 & 10 & 176 & 4.22 & 84.32 & baik \\
\hline 21 & 76 & 61 & 4 & 33 & 2 & 176 & 4.00 & 80.00 & baik \\
\hline 22 & 152 & 19 & 2 & 2 & 1 & 176 & 4.81 & 96.25 & sangat baik \\
\hline 23 & 153 & 20 & 1 & 1 & 1 & 176 & 4.84 & 96.70 & sangat baik \\
\hline Jumlah & 487 & 137 & 15 & 51 & 14 & 176 & 4.47 & 89.32 & baik \\
\hline
\end{tabular}

Sumber: pengolahan Data Primer, 2007

Berdasarkan hasil analisis yang terangkum pada tabel di atas dapat dijelaskan bahwa secara keseluruhan variabel hubungan guru di lingkungan keluarga adalah tergolong baik dengan rata-rata 4,47 (89,32\%). Beberapa aspek tergolong sangat baik adalah butir (a) tugas-tugas sekolah tidak menjadi sumber masalah antara suami/istri, (b) tidak perlu mengurangi aktivitas disekolah. Aspek yang tergolong baik adalah butir (a) saya menyelesaikan pekerjaan rumah tangga terlebih dahulu sebelum berangkat ke sekolah.

\section{F. Korelasi antara tingkat kompe-} tensi profesional dan kompetensi pedagogik terhadap kompetensi kepribadian guru RA/BA

Korelasi ini perlu dilakukan dengan berdasarkan pada satu asumsi bahwa guru yang memiliki kompetensi profesional dan pedagogik akan memiliki sikap dan kompetensi kepribadian yang positif terhadap tugasnya sebagai guru RA/BA, memiliki motivasi berprestasi dan memiliki sikap yang diteladani.

Berdasarkan hasil analisis regresi linear ganda terhadap pasangan data penelitian antara variabel kompetensi profesional $\left(\mathrm{X}_{1}\right)$ dan kompetensi pedagogik (X2) dengan kompetensi kepribadian $(\mathrm{Y})$ menghasilkan koefi-sien arah regresi $b_{1}$ sebesar $0,050, b_{2}$ sebesar 0,084 dan konstanta a sebesar 76.045. Dengan demikian, bentuk hubungan antara kedua variabel tersebut dapat dinyatakan oleh persamaan regresi $\mathrm{v}=76,05+0,050 \mathrm{X}_{1}$ $+0,084 \mathrm{X}_{2}$. Model persamaan regresi ini mengandung arti bahwa apabila kompetensi profesional dan kompetensi pedagogik ditingkatkan satu skor maka kecenderungan kompetensi kepriba-dian meningkat sebesar 0,134 skor pada konstanta 76,05. 
Analisis korelasi terhadap pasangan data dari kedua variabel tersebut menghasilkản koefisien korelasi $P_{\text {moduct }}$ moment sebesar $r_{y 1}=0,169$. dengan $t_{\text {hirung. }}=20.470>t_{\text {tabel }}=2,33$ pada taraf signifikansi $p=0,01$, jadi dapat disimpulkan bahwa koefisien korelasi $r_{y 1}=76,05$ signifikan. Dengan demikian, terdapat hubungan positif antara kompetensi profesional dan kompetensi pedagogik terhadap kompetensi kepribadian. Hal ini berarti semakin tinggi kompetensi profesional dan pedagogik, maka semakin tinggi pula kompetensi kepribadian.

Hasil analisis juga menunjukkan koefisien determinasinya sebesar 0,017 . Ini berarti $1,7 \%$ varians kompetensi profesional dan kompetensi pedagogik terhadap kompetensi kepribadian. Berarti sumbangan kompetensi profesional dan kompetensi pedagogik terhadap kompetensi kepribadian sebesar $1,7 \%$. Hal ini berarti banyak faktor selain kemampuan profesional dan pedagogik yang mempengaruhi kompetensi kepribadian.

\section{G. Korelasi antara tingkat kompe- tensi profesional dan Kompe- tensi Pedagogik terhadap} Kompetensi Sosial Guru RA/BA

Korelasi ini perlu dilakukan dengan berdasarkan pada satu asumsi bahwa guru yang memiliki kompetensi profesional dan pedagogik akan memiliki sikap dan kompetensi sosial yang positif terhadap hubungannya dengan sekolah, masyarakat dan keluarga.

Berdasarkan hasil analisis regresi linear ganda terhadap pasangan data penelitian antara variabel kompetensi profesional $\left(X_{1}\right)$ dan kompetensi pedagogik (X2) dengan kompetensi sosial (Y) menghasilkan koefisien arah regresi $b_{1}$ sebesar $0,106, b_{2}$ sebesar 0,103 dan konstanta a sebesar 66.402 . Dengan demikian, bentuk hubungan antara kedua variabel tersebut dapat dinyatakan oleh persamaan regresi $v=66,40+0,106 X_{1}+0,103 X_{2}$ Model persamaan regresi ini mengandung arti bahwa apabila kompetensi profesional dan kompetensi pedagogik ditingkatkan satu skor maka kecendetungan kompetensi sosial meningkat sebesar 0,209 skor pada konstanta 66,40 .

Analisis korelasi terhadap pasangan data dari kedua variabel tersebut menghasilkan koefisien korelasi Product moment sebesar $\mathrm{r}_{\mathrm{y} 1}=0,212$. dengan $t_{\text {hitung }}=14,668>t_{\text {tabel }}=2,33$ pada taraf signifikansi $\mathrm{p}=0,01$, jadi dapat disimpulkan bahwa koefisien korelasi $r_{y 1}=66,40$ signifikan. Dengan demikian, terdapat hubungan positif antara kompetensi profesional dan kompetensi pedagogik terhadap kompetensi sosial. 
Hasil analisis juga menunjukkan koefisien determinasinya sebesar 0,034. Ini berarti 3,4\% varians kompetensi profesional dan kompetensi pedagogik terhadap kompetensi kepribadian. Berarti sumbangan kompetensi profesional dan kompetensi pedagogik terhadap kompetensi sosial sebesar $3,4 \%$. Hal ini berarti banyak faktor selain kemampuan profesional dan pedagogik yang mempengaruhi kompetensi sosial.

\section{PENUTUP}

\section{A. Kesimpulan}

Hasil temuan penelitian kompetensi Guru RA/BA di 6 kota sasaran dapat disimpulkan sebagai berikut:

1. Tingkat kompetensi professional guru RA/BA dari enam kota/ kabupaten sasaran rata-rata tergolong kategori sedang, dengan rerata jawaban responden yang benar sebesar 27,99. Dari 6 wilayah yang menjadi lokasi penelitian diperoleh urutan skor tingkat kompetensi profesional dari yang terendah sampai yang tertinggi adalah: Gorontalo, Mataram, Batam, Balikpapan, DI Yogyakarta dan Denpasar.

2. Tingkat kompetensi pedagogik guru RA/BA rata-rata dari 6 daerah kota/kabupaten tergolong kategori sedang, dengan rerata jawaban responden yang benar sebesar 25,53. Dari 6 wilayah yang menjadi lokasi penelitian diperoleh urutan skor tingkat kompetensi pedagogik dari yang terendah sampai yang tertinggi adalah: Denpasar, Mataram, Gorontalo, Batam, Balikpapan dan Yogyakarta.

3. Tingkat kompetensi kepribadian guru RA/BA di 6 lokasi penelitian, dari segi minat dan sikap positif terhadap profesi guru termasuk kategori baik dengan rata-rata 4,28 (85,68\%). Variabel motivasi berprestasi tergolong cukup baik dengan rata-rata 3,53 (70,64 \%). Sedangkan variabel dari sikap yang diteladani oleh guru RA/BA adalah tergolong baik dengan rata-rata 4,31 $(86,15 \%)$.

4. Kompetensi sosial guru RA/BA dari 6 dari lokasi sasaran, yang terkait dengan variabel hubungan guru di lingkungan sekolah adalah tergolong Baik dengan rata-rata 4,05 (81,07\%), hubungan guru di lingkungan masyarakat tempat tinggal adalah tergolong cukup baik dengan rata-rata $3,78(75,64$ $\%$ ), Sedangkan variabel hubungan guru di lingkungan keluarga 
adalah tergolong baik dengan ratarata $4,47(89,32 \%)$.

\section{B. Rekomendasi}

1. Perlu peningkatan kompetensi Guru RA/BA secara terus menerus terutama dalam meningkatkan kompetensi profesional dan pedagogik.

2. Perlu dilakukan pembinaan RA/ BA secara maksimal, dari segi ketenagaan dan kelembagaan sehingga tercapai akreditasi guru sesuai dengan undang-undang

3. Peningkatan pengetahuan ketrampilan dalam pengembangan kurikulum dan metode pembelajaran tersebut dapat dilakukan melalui: Pendidikan dan pelatihan Guru $\mathrm{RA} / \mathrm{BA}, 2)$ peran lembaga musyawarah Guru dan 3) meningkatkan peran lembaga kelompok kerja guru (KKG).

4. Pendidikan dan pelatihan hendaknya dilakukan secara kontinue dalam rangka penyegaran pengetahuan dan ketrampilan mereka.

5. Pemberian kesempatan kepada guru RA/BA untuk melanjutkan pendidikan yang lebih tinggisesuai dengan bidangnya, mengingat semakin tinggi tingkat pendidi- kannya semakin baik juga tingkat kompetensinya.

\section{SUMBER BACAAN}

Arikunto, Suharsini (1990): Manajemen Petrgajaran Manusiawi. Jakarta, Rineka Cipta.

Bloom, Benjamin S (1982): Human Characteristic and School Learning. New York, McGraw-Hill Book Co.

HJ. Sriyanto, Pudarnya Citra Profesi Guru Internet: http: //www. Kompas. Com/kompas-cetak 301/07/opini/ 44670. htm), Selasa, 07 Januari 2003.

Depag RI (2004): Kurikulum Raudlaiul Atbfal Berbasis Kompetensi, Jakarta, Ditjen Bagais.

E. Mulyasa (2004): Kurikulum Berbasis Kompetensi (Konsep, Karakteristik dan implementasi). Bandung, Remaja Rosdakarya.Mungin Edi Wibowo (2003). Perlu Uji Kompetensi Bagi Guru Internet: http//www. kompas.com/ kompas-cetak/0307/15/jateng/ 432194,htm, 15 Juli.

Depdiknas (2004): Pedoman Pengembangan Silabus di Taman Kanak-Kanak. Jakarta, Departemen Pendidikan Nasional.

Purnomo, P. (2003): Kompotensi (Internet: http:// www sabda. Org/pepak/promo), Kamis, 11 Desember.

Soegito (2002): Peningkatan Kemampuan Profesional dan Kesejahteraan Guru (Internet: http://www.dittendik,net/ 
index 2 . php?option $=$ news\& 8 id $=19,13$ Nopember.

Qowaid dkk (2003): Profil Guru Pendidikan Agama di Sekolah Umum. Jakarta, Puslitbang Pendidikan Agama dan Keagamaan, Balitbang Agama dan Diklat Keagamaan.

Syah, Muhibuddin (1995): Psikologi Pendidikan; Suatu pendekatan Baru. Bandung, PT Remaja Rosdakarya.

Depdiknas (2003): Standar Kompetensi Pendidikan Anak Usia dini; TK dan RA. Jakarta, Pusat Kurikulum, Balitbang.

Peraturan Pemerintah Nomor 19 Tahun 2005 tentang Standar Nasional Pendidikan.
Undang-Undang Republik Indonesia Nomor 20 Tahun 2003 tentang Sistem Pendidikan Nasional

Undang-Undang Republik Indonesia Nomor 14 Tahun 2005 tentang Guru dan Dosen

Nawawi, Hadari (1992): Instrumen Penelitian Bidang Sosial. Yogyakarta, Gajah Mada University Pers.

Sukmadinata (1994): Pengembangan Kurikulum Teori dan Praktek. Jakarta, PT Remaja Rosda Karya.

Sudjana, Nana (1995): Dasar-Dasar Proses Belajar Mengajar. Bandung, CV. Sinat Baru.

Trianto dkk. (2007): Serifikasi Guru dan Upaya Peningkatan Kualifikasi, Kompetensi dan Kesejabteraan. Jakarta: Prestasi Pustaka. 